\title{
Effect of Recruitment and Selection Process on Employee Performance at PT Neckermann Utama Jakarta
}

\author{
Didin Hikmah Perkasa ${ }^{1}$, Ryani Dhyan Parashakti ${ }^{2}$, Yohana Prexi ${ }^{3}$ \\ \{didin.hikmah.perkasa@undira.ac.id ${ }^{1}$,ryani.dhyan.parashakti@undira.ac.id², \\ yprexi@yahoo.com ${ }^{3}$ \}

\begin{abstract}
Management Department, Faculty of Economy and Business, Universitas Dian Economy and Business, Universitas Dian Nusantara, West Jakarta, Jakarta, Dian Nusantara, West Jakarta, Jakarta, Indonesia ${ }^{3}$,
\end{abstract} \\ Nusantara, West Jakarta, Jakarta, Indonesia ${ }^{1}$, Management Department, Faculty of \\ Indonesia ${ }^{2}$, Management Department, Faculty of Economy and Business, Universitas
}

\begin{abstract}
The process of recruitment is one determinant of the success or failure of the company to accomplish its mission. With the process of recruitment and selection of appropriate and right can be obtained highly qualified human resources and produce a performance that will help the company towards its success. This study aims to determine the effect of recruitment, selection on the performance of the employee raises PT. Top Neckermann Jakarta. The population in this study were employees of PT. Top Neckermann Jakarta totaling 272 people. Samples used were as many as 162 people. Technics Slovin sampling method. To answer the problem formulation, purpose and hypothesis of this study, the analysis which used is the analysis of Statistical Product and Service Solutions (SPSS). Based on the analysis of Statistical Product and Service Solutions (SPSS), it was concluded that recruitment does not affect performance, and selection of an effect on the performance of employees at PT. Top Neckermann Jakarta.
\end{abstract}

Keyword: recruitment, selection, employee performance

\section{Introduction}

On in essence, human resources in the form of people employed in an organization as a driving force to achieve the goals of the organization. That is why it is often said that human resources are a very important factor[1], it cannot even be separated from an organization, both institutions and companies. Even today organizations do not view employees as mere resources, but rather as capital or major assets that are valuable, multiplied, and developed according to the company's business needs and orientation.

The human resource management activities consist of: human resource planning, procurement, direction, development, maintenance and dismissal. This is intended so that companies can manage their human resources effectively and efficiently.

One of the activities in human resource management is the recruitment and selection of employees. Recruitment is a process of gathering a number of applicants who have qualifications that match what the company needs to be employed in the company[2]. As for the benefits of recruitment, it has a function as "the Right Man on The Right Place", where this is a guide for managers in placing workers who match the job qualifications in their company. 
Recruitment is a series of activities to find and attract job applicants with the motivation, abilities, skills and knowledge needed to cover the deficiencies identified in staffing planning. The recruitment process is a process of recruiting prospective workers to meet the workforce needs (job vacancies) in a work unit within an organization or company.[3]

Meanwhile, the selection process is the process of selecting candidate workers who most meet the requirements to fill job vacancies. Thus, the recruitment process is the initial process carried out in the search for labor. Meanwhile, the selection process occurs after a number of employees have registered or registered through the recruitment process.

PT. Neckermann Utama is a company engaged in the footwear manufacturing industry. Starting from the Home Industry in the 1970s and standing under PD Twenty One Shoes. And since August 26, 1991 PD.Twenty One Shoes, changed its name to PT. Neckermann Utama, located in North Jakarta.Along with business competition and in an effort to improve the quality of human resources in the development of development in the State of Indonesia, on March 11, 2003, PT. Neckermann Utama was established in accordance with the provisions of the Law applicable to the Republic of Indonesia on the basis of the Notary Deed of Establishment Frans Elsius Muliawan, SH, No. 30, March 11, 2003 in Jakarta.

PT. Neckermann Utama produces ainternational quality foot weld with natural rubber material filled with anti-slip bubbles and covered by soft genuine Suede, so it is comfortable to wear. Careful workmanship with high technology alloys, Neckermann's products have become famous footwear from time to time until today with many fans among parents, young people and children.

Due to the increasing popularity of the footwear industry in the country, making Neckermann products finally had to be eliminated. However, since the last 3 (three) years, the management of PT. Neckermann Utama must think strategically in making important decisions, namely no longer producing other types of footwear and only focusing on adult male sandals with its main distribution to the Ramayana Department Store. This strategic business decision made PT. Neckermann Utama continues to survive by continuing to produce and sell adult men's sandals and always trying to improve the quality of human resources in a planned, consistent and sustainable manner.

Human resource management is indispensable for the effectiveness of human resources in organizations. The purpose of this is to provide work unit organizations that are effective and capable of achieving and knowing how the company should be able to develop, use and maintain employees in constant and gradual quality and quantity. Therefore, company management must be able to understand how best to manage employees who come from different backgrounds, skills and abilities so that employee performance can match the skills and types of work handled.

Depreciation that occurs is usually due to old age, death, termination of employment due to violations and negligence of work rules that have been set by PT. Neckermann Utama, or resigned due to several family problems, such as having to take care of children, following a husband who changed jobs and eventually requiring them to change residence, taking care of their sick parents, and other family problems that required them not to work anymore. Some cases are because there are job offers at other places with better income. Therefore, the new employees who will replace them have different tenure. To fill vacancies as a result of depreciation, the company is recruited through the authorized department, usually the Human Resources Department (HRD). Recruitment or recruitment is a process that aims to obtain a number of prospective employees who meet the requirements[4]. In the recruitment process, an effective selection process is needed, this is done to equalize employees so that the strength of human resources is more balanced. 
If the recruitment and selection of employees are not carried out properly, that is, they are not in accordance with correct and unfair company regulations or policies and procedures, then the recruited and selected workers may not have the ability to work in accordance with their job qualifications so that it can become a significant obstacle. which interferes with the process of achieving the company's vision and business goals. In fact, as one of the best footwear manufacturers with international quality, PT. Neckermann Utama must be able to continue to compete positively and excel with its competitors in producing quality footwear.

That is why, proper and fair implementation of recruitment and selection in accordance with the regulations or company policies and procedures of PT. Neckermann Utama is very important to pay attention to and implemented effectively and efficiently in order to obtain workers or employees who have adequate knowledge, skills and work attitudes or competencies in their fields so that they meet the principle of "Right Man on the Right Place", namely "assigning the right person to the type the right job ". Thus, individual employee performance will increase and have a direct impact on increasing the production value and company profits according to its business targets so that the company PT. Neckermann Utama will continue to develop even better in the future.

\section{Literature Review}

\subsection{Employee Performance}

Performance is a complete display of the state of the company for a certain period of time and is a result or achievement that is influenced by the company's operational activities in utilizing its resources. [5]. Performance is a term that is generally used for part or all of the actions or activities of an organization in a period with reference to a number of standards such as past or projected costs, on the basis of efficiency, responsibility, management and the like. Meanwhile, according to Mulyadi, performance is the periodic determination of the operational effectiveness of the organization, its parts of the organization and its employees based on predetermined goals, standards and criteria.

The main purpose of performance appraisal is to motivate individual employees to achieve organizational goals and to meet predetermined standards of behavior so as to produce the desired actions and results by the organization.[6]

Performance is also one of the total collections of work that is in the worker [7], [8]. Meanwhile, in other studies it is explained that performance is the result of the multiplication of motivation and ability[9]

\subsection{Recruitment}

Recruitment is a series of activities to find and attract job applicants with the necessary motivation, abilities, skills and knowledge to cover the deficiencies identified and required in staffing planning.[10]

Recruitment is the activity of finding and attracting job applicants with the motivation, skills, and knowledge of human resources needed by the organization to fill job vacancies that have been previously identified in the staffing plan.[11]. The purpose of recruitment is to get as much supply of potential applicants as possible so that the organization / company has the opportunity to choose prospective workers who meet the specified qualification standards.

Recruitment is the process of producing a number of qualified applicants for jobs in an organization or company[12]. Recruitment is basically a process to attract and determine applicants who are able to work in a company. 


\subsection{Selection}

Selection is a follow-up process after recruitment, where in the recruitment or withdrawal stage of employees, prospective employees will get information about job opportunities and positions at an agency or company. In the recruitment or job vacancy information, it is generally accompanied by the requirements needed. At this stage, management is not yet sure how many prospective employees and prospective employees will be accepted according to the needs of the institution or company. The number of prospective employees who meet the requirements will only be ascertained after going through an objective selection process by an authorized officer in the institution or company concerned. Some agencies / companies usually use the services of certain selection agencies or agents from outside the company.

The process of selecting from a group of applicants, persons or persons who best meet the selection criteria for an available position based on existing conditions carried out by the company [13].

\section{Methods}

The research was conducted at the company PT. Neckermann Utama Jakarta. The object of research is that most of the employees of PT. Neckermann Utama who worked at the front line management level and field employees. The population in this study were employees of PT. Neckremann Utama Jakarta, amounting to 272 people, while the sample was obtained using the Slovin formula as many as 162 respondents. The data collection technique in this study was to use a questionnaire measuring tool, namely by giving a set of written statements to respondents to answer. The questionnaire collection technique uses a survey method that aims to collect information obtained from respondents. The form of the questionnaire used is a closed questionnaire with a Likert scale. The analytical tool used in this research is SPSS.

\section{Results and Discussion}

The analysis requirements test used is the classical assumption test consisting of normality test, multicollinearity test and heteroscedasticity test. The normality test is carried out with PP Plot with the result that the points spread around the line and follow the diagonal line. Neither of the independent variables has a VIF value of more than 10.00 , so there is no multicollinearity between the independent variables in the regression model. The results of the Heteroscedasticity Test with a scatterplot show that the points are above and below the number 0 on the $\mathrm{Y}$ axis and do not have a pattern, so there is no heteroscedasticity. The feasibility of the model can be seen from the coefficient of determination of 0.345 and the adjusted $\mathrm{R}$ square of 0.337 , as shown in table 1

Table 1 Results of the Analysis of the Coefficient of Determination

\begin{tabular}{ccccc}
\hline Model & R & R Square & $\begin{array}{c}\text { Adjusted } \\
\text { R Square }\end{array}$ & $\begin{array}{c}\text { Std. Error } \\
\text { of the } \\
\text { Estimate } \\
1\end{array}$ \\
\hline $588 \mathrm{a}$ & .345 & .337 & 5.52698 \\
\hline
\end{tabular}


The $\mathrm{F}$ test is carried out to show whether all the independent variables included in the model have a joint influence on the dependent variable.

Table 2. F-Test Result

\begin{tabular}{cccc}
\hline & Model & F & Sig. \\
& Regression & 41,340 & $.000 \mathrm{~b}$ \\
1 & Residual & & \\
\hline
\end{tabular}

From the results of the SPSS output above, the sig value is $0.000 \leq 0.05$, it means that there is a significant effect, or it can be said that selection and recruitment simultaneously affect performance.

Table 3. Multiple Linear Regression

\begin{tabular}{|c|c|c|c|c|c|c|c|c|}
\hline & \multirow{2}{*}{ Model } & \multicolumn{2}{|c|}{$\begin{array}{c}\text { Unstandardized } \\
\text { Coefficients }\end{array}$} & \multirow{2}{*}{$\begin{array}{c}\begin{array}{c}\text { Standardize } \\
\mathbf{d} \\
\text { Coefficients }\end{array} \\
\text { Beta }\end{array}$} & \multirow{2}{*}{$\mathbf{t}$} & \multirow{2}{*}{ Sig. } & \multicolumn{2}{|c|}{$\begin{array}{c}\text { Collinearity } \\
\text { Statistics }\end{array}$} \\
\hline & & B & $\begin{array}{l}\text { Std. } \\
\text { Error }\end{array}$ & & & & $\begin{array}{c}\text { Toleranc } \\
\text { e }\end{array}$ & VIF \\
\hline & (Constant) & $\begin{array}{c}34,11 \\
5\end{array}$ & 3,695 & & $\begin{array}{c}9, \\
23 \\
2\end{array}$ & .000 & & \\
\hline 1 & recruitment & -155 & .127 & -116 & $\begin{array}{c}1, \\
22 \\
2\end{array}$ & .224 & .460 & $\begin{array}{c}2,17 \\
4\end{array}$ \\
\hline & selection & 1,043 & .148 & .667 & $\begin{array}{c}7, \\
05 \\
5\end{array}$ & .000 & .460 & $\begin{array}{c}2,17 \\
4\end{array}$ \\
\hline
\end{tabular}

The multiple linear regression equation in this study is formulated in a multiple regression model in this study formulated in a regression model as follows $\mathrm{Y}=\mathrm{a}+\mathrm{b} 1 \mathrm{X} 1+$ $\mathrm{b} 2 \mathrm{X} 2+\mathrm{e}$

The constant value (a) is the regression line intercept with $\mathrm{Y}$ if $\mathrm{X}=0$, which indicates that the size of the independent variable used in the research model is equal to that constant. The value of the constant (a) is 34,155 indicating that if the independent variable consisting of recruitment and selection $=0$, then the employee performance at PT. Neckermenn Utama amounted to 34,155 .

Recruitment regression coefficient $=-0.155$, indicating the direction of a negative and insignificant relationship between the recruitment variables and employee performance, this indicates that the recruitment system has not been running well and still needs a lot of improvement at PT. Neckermann Utama Jakarta. In other words, if the recruitment variable increases by 1 unit, the employee's performance at PT. Main Neckermenn will also increase by -0.155 , assuming the other variables are constant.

Selection regression coefficient $=0.143$, indicating the direction of the positive relationship (unidirectional) between the Selection variable and Employee Performance, this shows that the better the selection will further improve performance at PT. Neckermenn Main. 
In other words, if the recruitment variable increases by 1 unit, the employee's performance at PT. Main Neckermenn will also increase by 0.143 , assuming the other variables are constan

From the results of the multiple linear regression test, it can be concluded that the recruitment variable has a negative and insignificant relationship with the performance variable, which means that if the recruitment variable increases, the performance will also increase. Furthermore, from the results of the $T$ test, it is known that the recruitment variable has a sig value of $0.224>0.05$, which means that it is not significant, or in other words. So it can be said that the recruitment partially has no effect on performance.

From the results of the multiple linear regression test, it is concluded that the selection variable has a positive relationship with the performance variable, which means that if the selection variable increases, the performance will also increase. Furthermore, from the results of the $\mathrm{T}$ test it is known that the price variable has a sig value of $0.000<0.05$, which means that it is significant or in other words. So it can be said that selection partially affects performance.

\section{Conclusion}

Based on the results of research and discussion in the previous chapter, it can be concluded about the Effect of Recruitment and Selection Processes on Employee Performance at PT. Neckermann Utama Jakarta, namely:

1. Recruitment has no effect on performance, because at the time of recruitment PT. Neckermann Utama Jakarta has not been able to see the potential of prospective employees

2. Selection has an effect on performance, because at the time of selection, PT. Neckermann Utama Jakarta can see the potential of prospective employees

\section{References}

[1] M. T. E. Hariandja, Manajemen sumber daya manusia. Grasindo, 2002.

[2] H. J. Jackson and L. R. Malthis, "Manajemen sumber daya manusia Gramedia Jakarta," 2001.

[3] A. S. Munandar, Psikologi industri dan organisasi. Universitas Indonesia (UI-Press), 2001.

[4] M. S. Panggabean, "Manajemen sumber daya manusia," Bogor Ghalia Indones., vol. 85, 2004.

[5] E. A. Helfert and E. A. Helfert, Financial analysis: tools and techniques: a guide for managers. McGraw-Hill New York, 2001.

[6] J. S. Mulyadi, "Sistem perencanaan dan pengendalian manajemen," Yogyakarta: Aditya Media, 2001.

[7] M. J. Wells and M. J. Griffin, "A review and investigation of aiming and tracking performance with head-mounted sights," IEEE Trans. Syst. Man. Cybern., vol. 17, no. 2, pp. 210-221, 1987.

[8] V. Rivai and A. F. M. Basri, Performance Appraisal: Sistem yang tepat untuk menilai kinerja karyawan dan meningkatkan daya saing perusahaan. PT RajaGrafindo Persada, 2005.

[9] V. H. Vroom, "Work and motivation.," 1964.

[10] V. Rivai and E. J. Sagala, "Manajemen sumber Daya Manusia untuk Perusahaan, edisi kedua," Penerbit: Rajawali Pers, Jakarta, 2009.

[11] A. Sihotang, "Manajemen sumber daya manusia," Jakarta: Pradnya Paramita, 2007.

[12] L. Mathis Robert and H. Jackson John, "Manajemen Sumber Daya Manusia Buku 1," Ed. Pertama, Penerbit Salemba Empat, Jakarta, 2001.

[13] S. Henry, "Manajemen Sumber daya manusia," Yogyakarta STIE YKPN, 2004. 